\title{
Pre-Cretaceous Agaricomycetes yet to be discovered: Reinvestigation of a putative Triassic bracket fungus from southern Germany
}

\author{
Anna Philie Kiecksee ${ }^{1}$, Leyla J. Seyfullah ${ }^{1}$, Heinrich Dörfelt ${ }^{2}$, Jochen Heinrichs ${ }^{3}$, Herbert Süß ${ }^{4}$ \\ and Alexander R. Schmidt*, 1 \\ ${ }^{1}$ Courant Research Centre Geobiology, Georg-August-Universität Göttingen, Goldschmidtstraße 3, 37077 Göttingen, Germany. \\ E-mail: alexander.schmidt@geo.uni-goettingen.de \\ ${ }^{2}$ Mikrobielle Phytopathologie, Friedrich-Schiller-Universität Jena, Neugasse 25, 07743 Jena, Germany. \\ ${ }^{3}$ Albrecht-von-Haller-Institut für Pflanzenwissenschaften, Abteilung Systematische Botanik, Georg-August-Universität Göttingen, \\ Untere Karspüle 2, 37073 Göttingen, Germany. \\ ${ }^{4}$ Museum für Naturkunde, Leibniz-Institut für Evolutions- und Biodiversitätsforschung, Invalidenstraße 43, 10115, Berlin, Germany.
}

\begin{abstract}
Received 12 October 2011

Accepted 2 January 2012

Published 3 August 2012

\section{Key Words}

Basidiomycota

Fomes

Agaricomycetes are major components of extant terrestrial ecosystems; however, their fruiting bodies are exceedingly rare as fossils. Reinvestigation of a peculiar fossil from Late Triassic sediments of southern Germany interpreted as a bracket fungus revealed that this fossil in fact represents a wood abnormality, resulting from injury to the cambium and subsequent callus growth in a Baieroxylon-like ginkgoalean wood. As a result, the fossil record of the Agaricomycetes does not yet pre-date the Early Cretaceous, suggesting a late diversification of basidiomycetes possessing large fruiting bodies.
\end{abstract}

fossil fungi

fossil wood

Homobasidiomycetes

polypores

\section{Introduction}

The Agaricomycetes (= Homobasidiomycetes sensu Hibbett \& Thorn 2001 plus Auriculariales and Sebacinales; see Hibbett 2007) comprise about 21,000 extant species (Kirk et al. 2008). Although molecular phylogenetic analyses suggest a long evolutionary history of this group (see, e.g., Taylor \& Berbee 2006; Berbee \& Taylor 2007, 2010; Hibbett \& Matheny 2009), their fruiting bodies are rare as fossils. Records of representatives forming ephemeral mushrooms are mainly restricted to rare mid-Cretaceous to Miocene amber fossils (e.g., Poinar \& Singer 1990; Hibbett et al. 1997a, 2003; Poinar \& Buckley 2007). Longer-lasting fruiting bodies of bracket fungi, which primarily belong to the orders Polyporales and Hymenochaetales, were historically believed to date back to the late Paleozoic, how- ever, putative pre-Cretaceous records have been revised (see Fleischmann et al. 2007, for review). Also, Phellinites digiustoi Singer \& Archangelsky, 1958, the most convincing pre-Cretaceous polypore fossil from the Jurassic of Argentina (Singer \& Archangelsky 1958) was reassessed and found to be a piece of bark remains from an Araucariaceae representative (Hibbett et al. 1997b). Another putative fossil bracket fungus was later published from southern Germany and interpreted as a Fomes-like Polyporaceae representative attached to petrified wood (Fohrer \& Simon 2002). However, the interpretation by Fohrer \& Simon (2002) is based exclusively on external morphology. A closer investigation of this fossil, which would predate the oldest bona fide bracket fungi from the Early Cretaceous of Vancouver Island (Smith et al. 2004) by at least 88 million years is necessary by sectioning. Here, we present an

* Corresponding author 

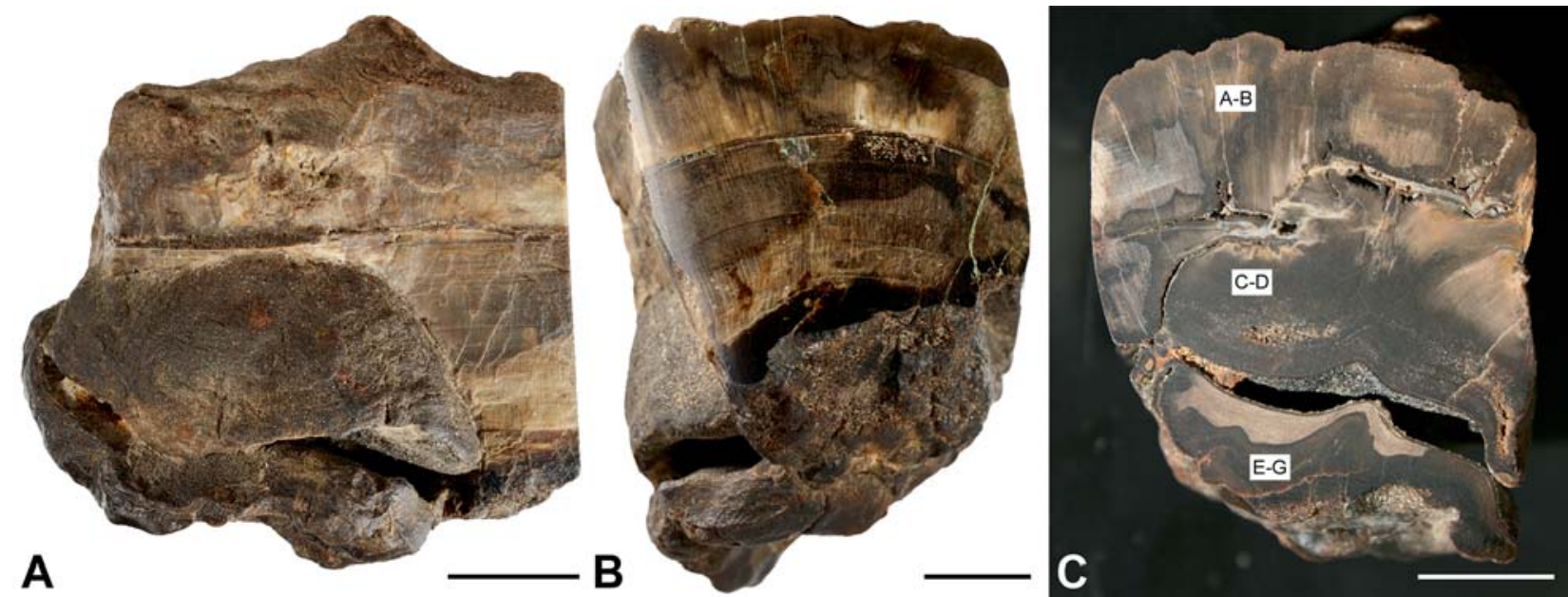

Figure 1. Overview of the Triassic ginkgoalean wood piece showing the abnormal structure within the interior of the wood. A. Fossil viewed longitudinally with respect to the preserved healthy wood, showing the dark protruding dome-shaped structure, which appears nearly split into two sections; B. Apical view of the polished healthy wood, shown in transverse section, with growth rings visible and the irregular abraded outer branch surface, and the protruding structure is visible on the side of the specimen; C. Transverse section of the fossil (with respect to the healthy wood) showing the transition from the healthy wood to the dome-shaped structure and its tripartite nature. Letters refer to areas magnified in Figure 2. Scale bars $10 \mathrm{~mm}$.

anatomical investigation of this currently sole remaining pre-Cretaceous putative bracket fungus and demonstrate that this fossil, too, is not fungal in nature. Rather, we provide evidence that this structure represents a wood abnormality, resulting from injury to the cambium and subsequent callus growth in a ginkgoalean wood that likely belongs to the morphogenus Baieroxylon.

\section{Material and methods}

The putative bracket fungus is attached to a piece of silicified wood which was polished on two sides by Erwin Fohrer (Gerabronn-Amlishagen, Germany) and preliminarily assigned to the cordaitalean genus Dadoxylon by Fohrer \& Simon (2002). The specimen was collected by Erwin Fohrer in a field near Reubach (southern Germany) and is likely to originate from a nearby outcrop exposing the Schilfsandstein of the Stuttgart-Formation (Fohrer \& Simon 2002) which is Carnian (224.5 to 226 million years) in age (Beutler et al. 1999).

For this reinvestigation, the half-dome shaped structure was sectioned perpendicularly to the wood's longitudinal axis. Thin sections of ca. $60 \mu \mathrm{m}$ were prepared from different areas along this transverse section through the area of interest and from the neighbouring wood tissue. The fossil was examined under incident (Carl Zeiss Stemi 2000) and transmitted light (Carl Zeiss AxioScope A1, equipped with Canon 450D digital cameras). The fossil is housed in the private col- lection of Erwin Fohrer; thin sections (GZG.PB.4999a-i) are deposited in the Geoscientific Collections of the Georg-August-University Göttingen (publication number \#1609).

\section{Results}

The fossil specimen, which measures $45 \times 40 \times 40 \mathrm{~mm}$ and is irregular, but roughly cuboidal in shape, represents a fragment of debarked wood from a stem or branch of a tree that is characterized by an unusual half-dome shaped structure protruding from within the wood tissue (Figs 1A, B). The wood to the exterior of the structure in question shows dense tissue varying in colour locally ranging from pale yellow to brown-black, with five clear growth rings which are partial growth rings as the specimen is incomplete, and an abraded outer surface, where the bark was stripped away prior to preservation (Fig. 1B). Towards one corner of the specimen, on the inside the wood fragment, a relatively smooth, dark bulbous structure protrudes longitudinally in relation to the wood. The surface of this structure is grey-black in colour and covered by minute crystals (Figs 1A, B). This structure is $25 \mathrm{~mm}$ high and $34 \mathrm{~mm}$

Figure 2. The Triassic ginkgoalean wood and its abnormal structure showing shared wood anatomy. All images show transverse sections, with respect to the wood, with $\mathrm{C}$ being a prepared thin section, the other images are of polished sections. A. Detail of healthy wood anatomy showing dense files of tracheids and a growth ring (arrowhead). Tissue lacks resin canals or secretory cells. Scale bar $500 \mu \mathrm{m}$; B. Detail of tracheid files showing the thickened cell walls and a half bordered pit (black arrowhead). A contrasting thin walled parenchyma ray is also visible (white arrowhead). Scale bar $100 \mu \mathrm{m}$; C. Thin section showing the transition from the healthy wood (left of image with three discernible growth layers) to a fissure separating this from the abnormal structure which shows a displaced continuation of two of these growth rings (arrowheads). Scale bar $1 \mathrm{~mm}$; D. Detail of the anatomy of the tissue from $\mathrm{C}$, inside the abnormal tissue area, showing files of thick walled tracheids and thin walled parenchyma rays. Scale bar $100 \mu \mathrm{m}$; E. Detail of callus formation area of the base of the abnormal growth region showing a disorganised wood anatomy. Scale bar $500 \mu \mathrm{m}$; F. Detail of callus formation area showing irregularly shaped tracheids with characteristically thinner cell walls in the left portion of the callus, giving a smeared appearance to the tissue. Scale bar $100 \mu \mathrm{m}$; G. Detail of E showing more irregularly shaped tracheids with thicker cell walls in the right of the disorganized tissue of the callus area. Scale bar $100 \mu \mathrm{m}$. 
wide at the maximum dimensions of its irregular hemispherical shape and has a conspicuous irregular fissure extending almost longitudinally the length of this structure, $5 \mathrm{~mm}$ wide and up to $20 \mathrm{~mm}$ deep, giving the appearance of splitting the structure (Figs 1A-C). The sides bordering the fissure are also covered by minute crystals. Parallel to the growth rings of the wood, and perpendicular to the bulbous surface, this structure has a clear irregular oval outline with a rough irregular surface, giving this area of the specimen a more 'gnarled'
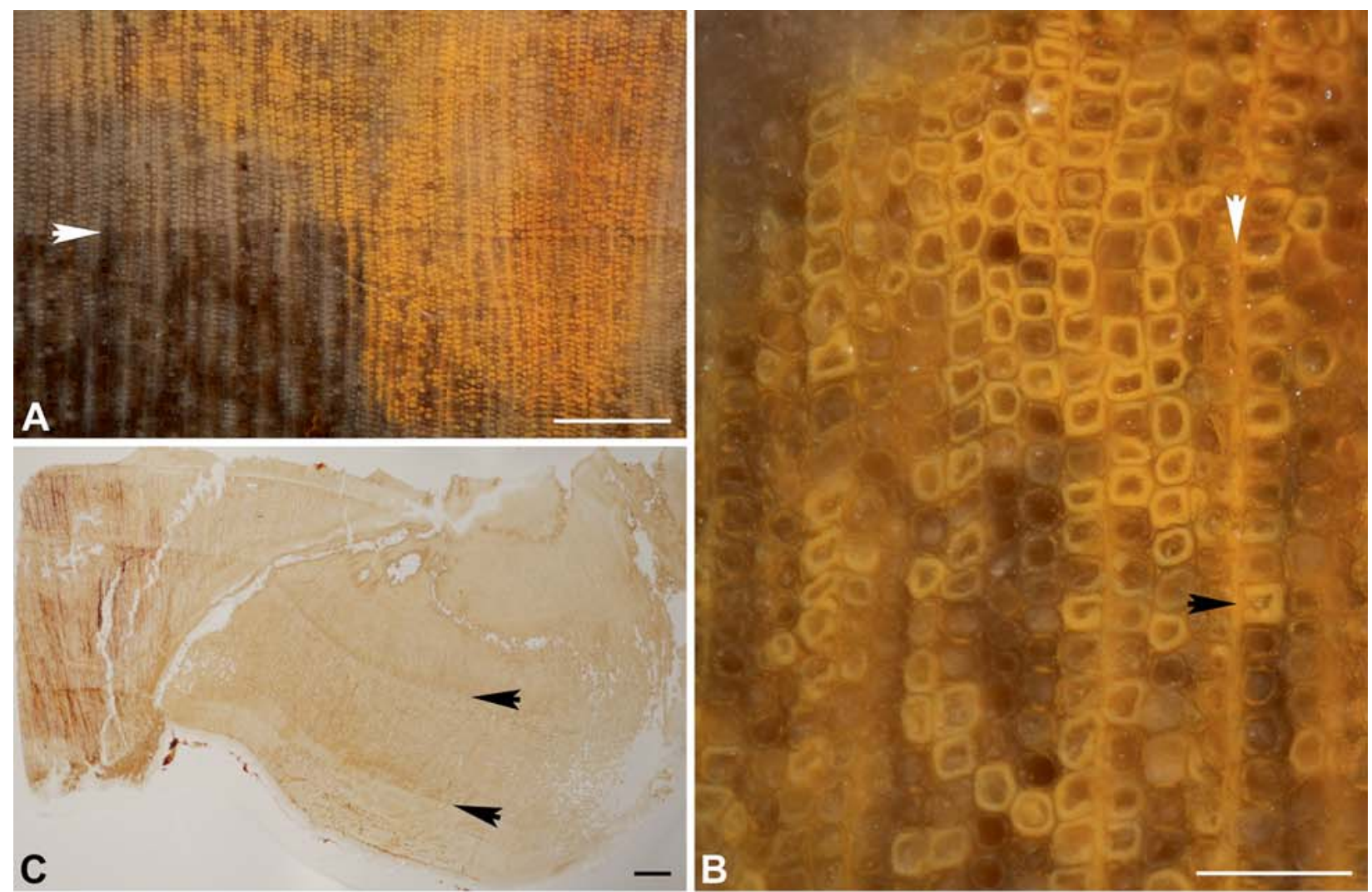

B
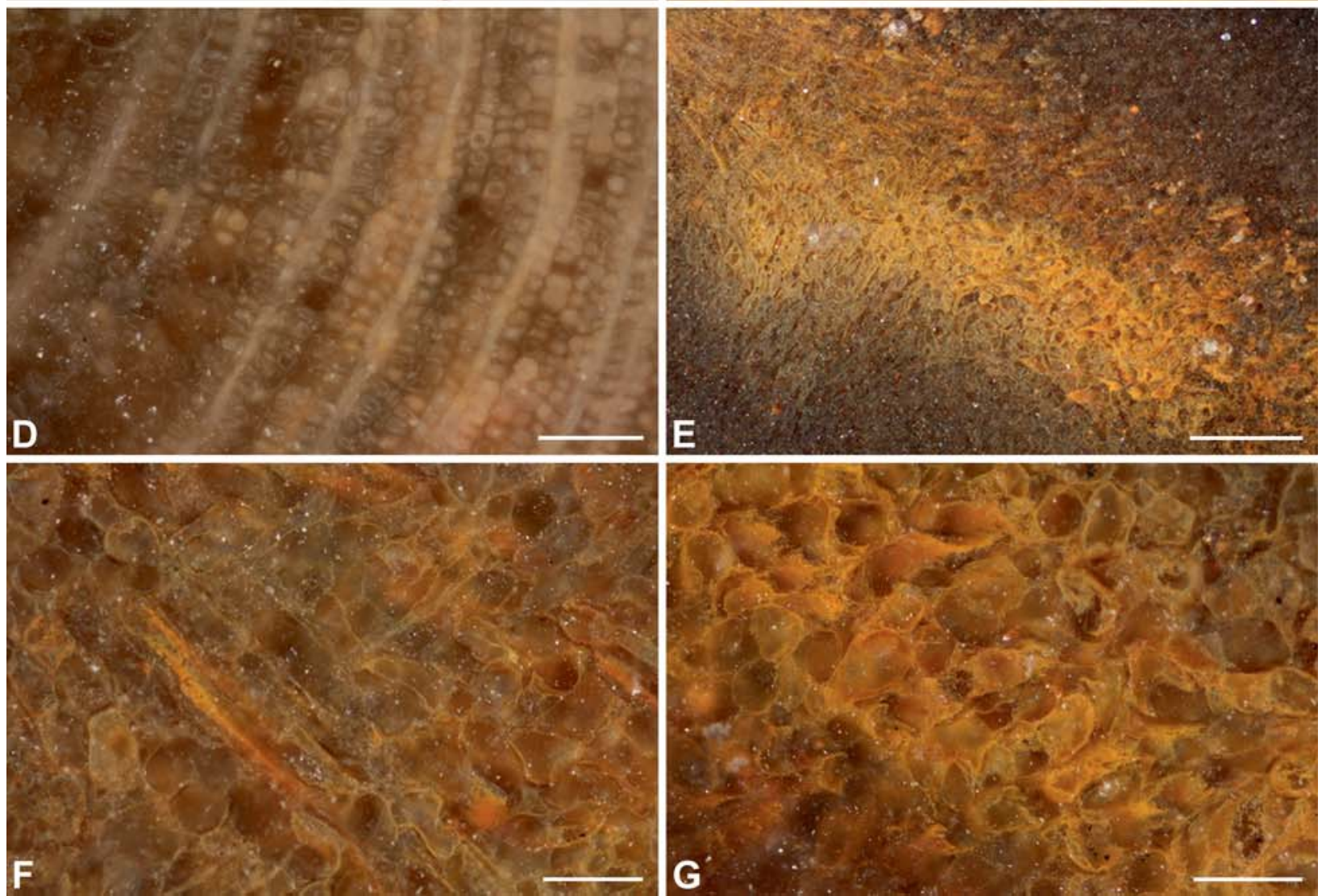
appearance (Figs 1A, B). The transition from the normal wood to the anomalous structure starts abruptly without an alteration of the adjoining wood tissue (Fig. 1C).

The transverse section reveals normally structured wood tissue in the regions near the exterior of the branch towards the abraded outer surface (Fig. 1C). The wood in transverse sections is composed of tracheids and rays arranged in uniform straight lines, extending perpendicularly to the outer debarked surface with arched growth rings observable (Figs 1B, 2A). The tracheids are predominantly rectangular (sometimes circular) in diameter and on average measure $30 \times 40 \mu \mathrm{m}$ (Fig. 2B). The tracheids exhibit thickened white-yellow secondary cell walls, averaging $5 \mu \mathrm{m}$ wide, and half bordered pits opposite ray cells (Fig. 2B, black arrowhead). The radial sections, where preservation allows, show the tracheids are long and thin $(260-510 \mu \mathrm{m}$ long, 15-25 $\mu \mathrm{m}$ wide) and that the tracheid radial walls have single rows of circular abietinoid pits $10-12 \mu \mathrm{m}$ in diameter. Two growth rings are observable in this portion of the healthy wood. Between the rows of tracheids are scattered narrow columns of single (uniseriate) long, thin parenchyma rays with delicate cell walls (Fig. 2B, white arrowhead). There are no observable secretory cells or resin canals. Secondary structures of the cell walls are not preserved.

Towards the inside of the wood, smaller fissures of up to $500 \mu \mathrm{m}$ wide become apparent which separate the healthy wood from the prominent structure (Fig. 1C) with a strong discouloration at the fissure margins. The structure comprises three portions of barely discernible radiating patterns of cellular growth with some disrupted and disorganized areas, two portions of which abut in the upper part of the dome shape (Fig. 1C). The tissue within these three areas is less uniform in structure than that of the healthy wood (Figs 1C, 2C). At the border of the healthy wood to the anomalous structure, two of the growth rings are seen to continue towards the inside of one of these areas of the structure with a slight displacement (Fig. 2C, arrowheads) showing that the cells at the top of the dome shaped structure are also rectangular in shape and of similar size as the tracheids of the healthy wood, and are also arranged in files (Fig. 2D).

In the basal part of the domed structure the original callus formation area is apparent (Fig. 2E), characterized by a disruption of the cellular organization (Figs 2E-G). The thick-walled xylem cells are at times extended in a radial direction and appear sheered from the regular linear formation of healthy wood tissue, giving the tissue a smeared appearance (Figs 2F, G) and a more randomized appearance to these cells. More frequently the cells appear longer and in less regular shapes than those of the healthy wood tissue (Figs 2F, G). Scattered very long and thin parenchyma cells $(320 \times 15 \mu \mathrm{m})$ are also present (Fig. 2F). None of the transverse, radial sections or the thin-sections indicate the presence of secretory cells or resin canals in the healthy wood tissue or the anomalous structure and no hyphae or other fungal structures are observed.

\section{Discussion}

The incompleteness of the preservation of the wood and its level of decomposition prior to preservation means that some diagnostic features are lost, in particular the details of the secondary thickening of the tracheid walls. This precludes a detailed assignment of this wood to a morphogenus. Nevertheless, based on wood anatomical features it is safe to say that it is a gymnospermous wood fragment. The anatomy and arrangement of the tracheids and pitting on the radial tracheid walls, together with the ray cells and the lack of secretory cells or resin canals suggest that this branch piece may belong to a fragment of Baieroxylon, a Triassic wood morphogenus with affinities to the ginkgophytes.

Reinterpretation of the fossil structure described by Fohrer \& Simon (2002) shows that the fossil record of the Agaricomycetes still does not yet pre-date the Early Cretaceous. Dennis (1970) reported a mycelium possessing clamp connections from Carboniferous wood suggesting the occurrence of Basidiomycota, or possibly even ancestors of the Agaricomycetes, in the late Paleozoic. However, the oldest accepted agaricomycete is still Quatsinoporites cranhamii Smith, Currah \& Stockey, 2004 (Smith et al. 2004), an abraded fragment of a Hymenochaetales representative from Lower Cretaceous strata of Vancouver Island. The age was originally reported as Barremian by Smith et al. (2004), but the sediments have since been reported to be older at $136 \mathrm{Ma}$ which places this fossil on the Valanginian-Hauterivian boundary (Stockey \& Wiebe 2008). Current finds revealed further Early Cretaceous remains of Hymenochaetales representatives in insect faecal pellets enclosed in ca. 100 million-year-old Albian amber of south-western France (Schmidt et al. 2010). Fossils of bracket fungi become more abundant in the Cenozoic (for review, see Tiffney \& Barghoorn 1974; and Fleischmann et al. 2007) and gilled mushrooms are recorded as amber inclusions since the mid-Cretaceous; Palaeoagaracites antiquus Poinar \& Buckley, 2007 from the Albian-Cenomanian of Myanmar (Poinar \& Buckley 2007) and Archaeomarasmius leggetti Hibbett, Grimaldi \& Donoghue, 1997 from the Turonian of New Jersey (Hibbett et al. 1997a) being the only Cretaceous representatives described to date. Molecular phylogenetic analyses tend to a much older than Cretaceous (probably late Paleozoic to early Mesozoic) age of origin of the Agaricomycetes; however, these analyses currently still provide very conflicting results, depending on tree topology and prior probabilities used (for discussion, see, e.g., Taylor \& Berbee 2006; Berbee \& Taylor 2007, 2010; and Hibbett \& Matheny 2009). An alternative view of these results is that the molecular data provide evidence that older Agricomycetes fossils may exist, but that these fossils have not yet been discovered. 


\section{Acknowledgements}

We are grateful to Erwin Fohrer (Gerabronn-Amlishagen) and to Theo Simon (Fichtenberg) for providing the specimen for reinvestigation as well as for preparation permission and fruitful discussion. We thank Christina Beimforde (Göttingen) and Kerstin Schmidt (Jena) for useful comments and Joachim Reitner (Göttingen) for support as well as Axel Hackmann (Göttingen) and Hans-Rudolf Knöfler (Berlin) for preparing the thin sections. Gerhard Hundertmark (Göttingen) kindly provided the images of Figs $1 \mathrm{~A}$ and $\mathrm{B}$. We are grateful to the reviewers of the manuscript, Michael Krings (München) and Barbara Mohr (Berlin), for their constructive suggestions. The contribution from LJS was funded by the Dorothea Schlözer Programme at the Georg-August-Universität Göttingen. This is publication number 73 from the Courant Research Centre Geobiology that is funded by the German Initiative of Excellence.

\section{References}

Berbee, M. L. \& Taylor, J. W. 2007. Rhynie chert: a window into a lost world of complex plant - fungus interactions. - New Phytologist 174: 475-479.

Berbee, M. L. \& Taylor, J. W. 2010. Dating the molecular clock in fungi - how close are we? - Fungal Biology Reviews 24: 1-16.

Beutler, G., Hauschke, N. \& Nitsch, E. 1999. Faziesentwicklung des Keupers im Germanischen Becken. In Hauschke, N. \& Wilde, V. (eds). Trias - Eine ganze andere Welt. Mitteleuropa im frühen Erdmittelalter. Verlag Dr. Friedrich Pfeil, München: pp. 129-174.

Dennis, R. L. 1970. A Middle Pennsylvanian Basidiomycete mycelium with clamp connections. - Mycologia 62: 578-584.

Fleischmann, A., Krings, M., Mayr, H. \& Agerer, R. 2007. Structurally preserved polypores from the Neogene of North Africa: $G a$ nodermites libycus gen. et sp. nov. (Polyporales, Ganodermataceae). - Review of Palaeobotany and Palynology 145: 159-172.

Fohrer, E. \& Simon, T. 2002. Baumpilze und Trüffel. Höhere Pilze aus dem Keuper, Teil 1. - Fossilien 19: 360-362.

Hibbett, D. S. 2007. Agaricomycetes. Mushroom-Forming Fungi. Version 20 April 2007. - http://tolweb.org/Agaricomycetes/20535/ 2007.04.20 In The Tree of Life Web Project, http://tolweb.org/.
Hibbett, D. S. \& Matheny, P. B. 2009. The relative ages of ectomycorrhizal mushrooms and their plant hosts estimated using Bayesian relaxed molecular clock analyses. - BMC Biology 7: 13 .

Hibbett, D. S. \& Thorn, R. G. 2001. Basidiomycota: Homobasidiomycetes. In McLaughlin, D. J., McLaughlin, E. G. \& Lemke, P. A. (eds). The Mycota. Vol. VII, part B. Springer-Verlag, Berlin: pp. $121-168$.

Hibbett, D. S., Grimaldi, D. \& Donoghue, M. J. 1997a. Fossil mushrooms from Miocene and Cretaceous ambers and the evolution of homobasidiomycetes. - American Journal of Botany 84: 981991.

Hibbett, D. S., Donoghue, M. J. \& Tomlinson, P. B. 1997b. Is Phellinites digiustoi the oldest homobasidiomycete? - American Journal of Botany 84: 1005-1011.

Hibbett, D. S., Binder, M., Zheng Wang \& Goldman, Y. 2003. Another fossil agaric from Dominican amber. - Mycologia 95: 685687.

Kirk, P. M., Cannon, P. F., Minter, D. W. \& Stalpers, J. A. 2008. Dictionary of the Fungi. 10th edition. CAB International, Wallingford.

Poinar, G. O. \& Buckley, R. 2007. Evidence of mycoparasitism and hypermycoparasitism in Early Cretaceous amber. - Mycological Research 111: 503-506.

Poinar, G. O. \& Singer, R. 1990. Upper Eocene gilled mushroom from the Dominican Republic. - Science 248: 1099-1101.

Schmidt, A. R., Dörfelt, H., Struwe, S. \& Perrichot, V. 2010. Evidence for fungivory in Cretaceous amber forests from Gondwana and Laurasia. - Palaeontographica, Abteilung B 283: 157-173.

Singer, R. \& Archangelsky, S. 1958. A petrified basidiomycete from Patagonia. - American Journal of Botany 45: 194-198.

Smith, S. Y., Currah, R. S. \& Stockey, R. A. 2004. Cretaceous and Eocene poroid hymenophores from Vancouver Island, British Coulmbia. - Mycologia 96: 180-186.

Stockey, R. A. \& Wiebe, N. J. P. 2008. Lower Cretaceous conifers from Apple Bay, Vancouver Island: Picea-like leaves, Midoriphyllum piceoides gen. et sp. nov. (Pinaceae). - Botany 86: 649-657.

Taylor, J. W. \& Berbee, M. L. 2006. Dating the divergences in the Fungal Tree of Life: review and new analyses. - Mycologia 98: $838-849$.

Tiffney, B. H. \& Barghoorn, E. S. 1974. The fossil record of fungi. Occasional Papers of the Farlow Herbarium 7: 1-42. 